2003年の鉱工業生産は前年比 $3.2 \%$ と年ぶりに上昇となった。 これを四半期別にみると，1 3月期が前期比 $0.3 \%$ 上昇，4 6月 期が同・0.7\%低下と小幅な動きが続いたが，7〜9月期が同 $1.3 \% ， 10 \sim 12$ 月期が同3.7\%と上昇を続け，持直しの動きがみ られた.

財別にみると，建設財（前年比 $\mathbf{A} 2.9 \% ， 3$ 年連続），非耐久消 費財（同 $\mathbf{\Delta} 0.7 \% ， 4$ 年連続）が低下となったものの，資本財 (同1.7\%，3年ぶり), 耐久消費財 (同 $2.0 \%, 3$ 年ぶり), 生産財 （同6.1\%，2年連続）が上昇となった。

業種別にみると（表 2 ）, 電子部品・デバイス工業, 一般機 械工業など 10 業種で上昇, 繊維工業, 金属製品工業など 7 業種 で低下となった。また，内外需別に出荷をみると，国内向けは 前年比 $3.9 \%$ と 3 年ぶりの上昇, 輸出向けは同 $4.1 \%$ と 2 年連続の 上昇となった。

2003年に増加した主な品目としては，携帯電話，ディジタル カメラ向けなどが増加したことにより，モ不型半導体集積回路 （メモリ）が前年比 $39.7 \%$ と 2 年連続，アクティブ型液晶素子 (中・小型) が同 $91.9 \%$ とアクティブ型液晶素子（大型）と分割 された 10 年以降5年連続，14年から集計が開始されたモス型半 導体集積回路（CCD）が同 $84.9 \%$ とそれ帒れ増加，携帯電話向 けが好調に推移したリチウムイオン蓄電池が同 $40.4 \%$ と 2 年連続 の增加, 携带電話が高画素数のカメラ付携帯電話など高機能の 新製品が投入されたことにより同 $28.8 \%$ と 3 年ぶりの増加となっ た。一方，減少した主な品目としては，公共工事の減少などに より橋りょうが前年比 $\mathbf{\Delta} 19.2 \%$ と 3 年連続の減少，小型乗用車は 国内向け，アメリカ向け輸出などが減少したことにより同 $5.6 \%$ と 2 年ぶりの減少, ディジタル伝送装置が電気通信事業者 の設備投資の減少により同へ $65.3 \%$ と 3 年連続の減少，パーソナ ルコンピュータは海外生産が進展したことにより同ム12.4\%と3 年連続の減少，国内向けおよびアメリカ向け輸出が減少したこ とにより一般用蒸気タービンが同 $\mathbf{\Delta} 21.2 \%$ と年連続の減少とな った.

\section{1:1:4 業種別の動向}

同じく経済産業省が発表した「平成15年年間回顧・産業活動 分析」で，次のようにまとめられている.

a. 鉄鋼業生産は, 産業用機械向け扰よび自動車向け需 要の増加から, 前年比 $4.1 \%$ と 2 年連続の上昇, 出荷は, 素製品, 鋼管を除くすべての業種が増加したことにより同 $4.2 \%$ と 2 年連 続の上昇, 在庫は, 鋳鍛造品を除くすべての業種が増加したこ とにより前年末比 $5.5 \%$ と年ぶりの上昇，在庫率は，前年比 $1.4 \%$ と 2 年連続の低下となった。

b. 非鉄金属工業生产は，非鉄金属鋳物，伸銅・アルミ 二ウム圧延製品，非鉄金属地金が増加したことにより前年比 $1.9 \%$ と 3 年ぶりの上昇, 出荷は, 非鉄金属鋳物，伸銅・アルミ 二ウム圧延製品，非鉄金属地金が増加したことにより同1.6\%と 3 年ぶりの上昇, 在庫は, 前年末比 $0.5 \%$ と 5 年ぶりの上昇, 在庫 率は，前年比・3.4\%と2年連続の低下となった。

c. 金属製品工業生産は，建設用金属製品，建築用金属 製品が減少したことにより前年比 $\boldsymbol{A} 2.5 \%$ と 3 年連続の低下，出 荷は，建設用金属製品，建築用金属製品，その他の金属製品が 減少したことにより同 $\mathbf{A} 2.3 \%$ と年連続の低下，在庫は，前年
末比 $\Delta 1.1 \%$ と 2 年連続の低下，在庫率は，前年比 $\Delta 3.6 \%$ と 2 年 連続の低下となった。

d. 一般機械工業生産は, 特殊産業機械, 土木建設機械, 風水力機械・油圧機器, 金属工作機械, 産業用口ボットなどが 増加したことにより前年比7.0\%，出荷は同7.1\%と，いずれも3 年ぶりの上昇, 在庫は, 冷凍機・同応用製品, 土木建設機械, 金属工作機械，農業用機械，機械工具などが減少したことによ り，前年末比 $\mathbf{A} 7.7 \%$ と 2 年連続の低下，在庫率は前年比 $\boldsymbol{\Delta} 18.6 \%$ と，2年連続の大幅な低下となった。

e. 電気機械工業生産は, 電池, 電気計測器などが増加 したことにより前年比 $6.0 \%$ と年ぶりの上昇, 出荷も, 電池, 電気計測器などが増加したことにより同 $6.6 \%$ と年ぶりの上昇, 在庫は, 前年末比 $\Delta 4.1 \%$ と 5 年連続の低下, 在庫率は, 前年比 A 7.4\%と2年連続の低下となった。

f. 情報通信機械工業 生産は，電子計算機が減少したも のの, 民生用電子機械, 通信機械が増加したことにより前年比 $3.8 \%$ と 3 年ぶりの上昇, 出荷は, 電子計算機が減少したものの, 民生用電子機械，通信機械が増加したことにより同 $5.4 \%$ と 3 年 ぶりの上昇, 在庫は, 前年末比 $7.2 \%$ と 3 年ぶりの上昇, 在庫率 は，前年比 $1.2 \%$ と年ぶりの上昇となった。

g. 電子部品・デバイスエ業生産は，モス型半導体集積 回路 (メモリ), アクティブ型液晶素子 (中・小型), モス型半 導体集積回路 (CCD) の大幅増により集積回路, 電子部品など すべての業種で増加したことにより前年比 $17.9 \%$ と 2 年連続の 上昇, 出荷は, 電子部品, 集積回路などすべての業種で増加し たことにより同 $20.2 \%$ と 2 年連続の上昇, 在庫は, 電子部品が増 加したものの, 集積回路が減少に転じたこと, 半導体素子が引 き続き減少したことにより前年末比入 $8.7 \%$ と 3 年連続の低下， 在庫率は，前年比 $\boldsymbol{\Delta} 18.3 \%$ と 2 年連続の低下となった。

h. 輸送機械工業生産は, 自動車部品, トラック，鉄道 車両, 産業車両が増加したことにより, 前年比 $0.3 \%$ と 2 年連続 の上昇, 出荷は, 自動車部品, トラック, 乗用車などが増加し たことにより，同 $3.1 \%$ と 2 年連続の上昇，在庫は，乗用車，自 動車部品が減少したことにより，前年末比 $\mathbf{A} 8.2 \%$ と 2 年ぶりの 低下となった。

i. 精密機械工業 生産は, 光学機械・同部品, 時計が減少 したものの, 計測機器が増加したことにより前年比 $2.9 \%$ と年 ぶりの上昇, 出荷は, 計測機器が増加したものの, 光学機械・ 同部品，時計が減少したことにより同ム $4.4 \%$ と年連続の低下， 在庫は, 時計, 計測機器, 光学機械・同部品のすべての業種が 減少したことにより前年末比 $\mathbf{A} 12.7 \%$ と 2 年連続の低下，在庫率 は，前年比・ $14.0 \%$ と年連続の低下となった。

j. 窯業・土石製品工業 生産は，前年比は $\mathbf{\Delta} 2.7 \%$ と 3 年連 続の低下となった。これは，ガラス・同製品は建築需要や自動 車向けが好調な板ガラス，安全ガラスなどの増加から同 $2.5 \%$, その他の案業・土石製品はせっこうボードや生石扊などの増加 から同 $1.8 \%$ と，ともに 3 年ぶりの増加となったものの，セメン 卜・同製品が公共工事の減少から同 $\mathbf{A} 7.1 \%$ と年連続減少した ほか, 陶磁器・ファインセラミックスがタイル, 台所・食卓用 陶磁器などの減少から同 $\mathbf{A} 3.6 \%$ と 3 年連続の減少となったこと による．出荷は同 $\mathbf{\Delta} 4.1 \%$ と 3 年連続の低下，在庫は，同 $\boldsymbol{\Delta} 3.0 \%$ と2年連続の低下となった。

k. 化学工業（除. 医薬品）生産は, 写真感光材料, 化学 
表 2 業種別生産動向（2003年）

\begin{tabular}{|c|c|c|c|c|c|}
\hline & \multirow{2}{*}{$\begin{array}{c}\text { 生 産 } \\
4.0 \% \text { 上昇 }\end{array}$} & \multirow{2}{*}{$\begin{array}{c}\text { 前年比 } \\
(\%)\end{array}$} & \multirow{2}{*}{ 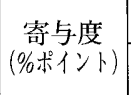 } & \multicolumn{2}{|c|}{ 品目 } \\
\hline & & & & 増 加 & 減 \\
\hline \multirow{6}{*}{$\begin{array}{c}\text { 加 } \\
\text { 工 } \\
\text { 型 } \\
\text { 業 } \\
\text { 種 } \\
8.0 \% \\
\text { 〔4.01〕 }\end{array}$} & 電子部品・デバイス工業 & 20.2 & 2.15 & $\begin{array}{l}\text { アクティブ型液晶素子 (中・小型) } \\
\text { モ不型半導体集積回路 (メモリ) } \\
\text { モ不型半導体集櫝回路 (ロジック) }\end{array}$ & $\begin{array}{l}\text { スイッチング電源 } \\
\text { 整流素子 } \\
\text { 磁気へッド }\end{array}$ \\
\hline & 一般機械工業 & 7.1 & 0.73 & $\begin{array}{l}\text { ショべル系掘削機械 } \\
\text { 半導体製造装置 } \\
\text { はんん用内燃機関 }\end{array}$ & $\begin{array}{l}\text { 水管ボイラ } \\
\text { 般用蒸気タービン } \\
\text { プレス金型 }\end{array}$ \\
\hline & 輸送機械工業 & 3.1 & 0.55 & $\begin{array}{l}\text { 普通自動車 } \\
\text { 駆動伝導・操縦装置部品 } \\
\text { 普通トラック } \\
\end{array}$ & $\begin{array}{l}\text { 小型乗用車 } \\
\text { 軽釆用車 } \\
\text { 二.輪自動車（125m } l \text { 以下） }\end{array}$ \\
\hline & 情報通信機械工業 & 5.4 & 0.33 & $\begin{array}{l}\text { ディジタルカメラ } \\
\text { 携帯電話 } \\
\text { ビデオカメラ }\end{array}$ & $\begin{array}{l}\text { パーソナルコンピュータ } \\
\text { ディジタル伝送装置 } \\
\text { 入出力機器 }\end{array}$ \\
\hline & 電気機械工業 & 6.6 & 0.31 & 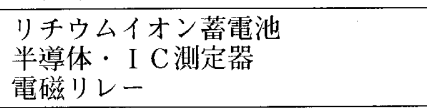 & $\begin{array}{l}\text { 開閉制御装置 } \\
\text { アルカリ竜池 } \\
\text { セパレート型エアコン }\end{array}$ \\
\hline & 精密機械工業 & $\mathbf{A}_{4.4}$ & $\boldsymbol{\Delta}_{0.03}$ & $\begin{array}{l}\text { 分析機器 } \\
\text { 精密測定機 } \\
\text { 工業用長さ計 }\end{array}$ & $\begin{array}{l}35 \mathrm{~mm} \text { カメラ } \\
\text { ガスメータ } \\
\text { カメラ用交換レンズ }\end{array}$ \\
\hline \multirow{6}{*}{$\begin{array}{c}\text { 素 } \\
\text { 形 } \\
\text { 材 } \\
\text { 業 } \\
\text { 種 } \\
\mathbf{\Delta} 0.0 \% \\
\text { [^0.00] }\end{array}$} & 鉄鋼業 & 4.2 & 0.20 & $\begin{array}{l}\text { 特殊鋼熱間圧延鋼材 } \\
\text { 央鉛めつさ鋼板 } \\
\text { 普通鋼鋼板 }\end{array}$ & $\begin{array}{l}\text { 小形棒鋼 } \\
フ ェ \text { ア } \\
\text { フ特殊鋼熱口間鋼管 }\end{array}$ \\
\hline & 化学工業 & 1.3 & 0.12 & $\begin{array}{l}\text { ポリプロピレン } \\
\text { 皮膚用化粧品 } \\
\text { スチレンモー }\end{array}$ & 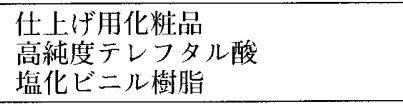 \\
\hline & 非鉄金属工業 & 1.6 & 0.04 & $\begin{array}{l}\text { アルミニウム圧延製品 } \\
\text { ダイカスト } \\
\text { 電気菳 }\end{array}$ & $\begin{array}{l}\text { 通信用ケーブル光ファイバ製品 } \\
\text { 通信用電線・ケーブル } \\
\text { アルミニ線 }\end{array}$ \\
\hline & パルプ・紙・紙加工品工業 & $\Delta 0.5$ & $\mathbf{\Delta}_{0.02}$ & $\begin{array}{l}\text { 情報用紙 } \\
\text { 段ボールシート }\end{array}$ & $\begin{array}{l}\text { 印刷用紙 (非塗工類) } \\
\text { 印刷用紙 (塗工) } \\
\text { 衛生用紙 }\end{array}$ \\
\hline & 窯業·土石製品 T.業 & $\mathbf{\Delta} 4.1$ & $\mathbf{\Delta}_{0.14}$ & $\begin{array}{l}\text { 板ガラス } \\
\text { 生石炏 } \\
\text { 石こうボード }\end{array}$ & $\begin{array}{l}\text { セメント } \\
\text { ガラス基礎製品 } \\
\text { 道路用コンクリート製品 }\end{array}$ \\
\hline & 繊維工業 & $\mathbf{\Delta} 8.7$ & $\mathbf{\Delta}_{0.21}$ & & $\begin{array}{l}\text { ニット製外衣 } \\
\text { 織物製外衣 } \\
\text { 合成繊維 (短䋊維) }\end{array}$ \\
\hline \multirow{5}{*}{$\begin{array}{c}\text { そ } \\
\text { の } \\
\text { 他 } \\
の \\
\text { 業 } \\
\text { 種 } \\
\Delta 0.4 \% \\
\text { [ } 0.40 .11]\end{array}$} & 金属製品工業 & $\mathbf{\Delta} 2.3$ & $\mathbf{\Delta}_{0.10}$ & $\begin{array}{l}\text { 木造位宅用アルミニウムサッシ } \\
\text { 超硬チップ } \\
\text { 鋼索 }\end{array}$ & $\begin{array}{l}\text { 橋りょう } \\
\text { 产業用アルミニウム製品 } \\
\text { ビル用アルミニウム製品 } \\
\end{array}$ \\
\hline & その他工業 & $\mathbf{\Delta} 1.7$ & $\mathbf{\Delta}_{0.07}$ & $\begin{array}{l}\text { 自転車用タイヤ } \\
\text { 業用ゴム製品 } \\
\text { 金属製間仕切り }\end{array}$ & $\begin{array}{l}\text { 電子忍用がん具 } \\
\text { 革 } \\
\text { 木製棚 } \\
\end{array}$ \\
\hline & 食料品・たばこ工業 & $\Delta 0.6$ & $\mathbf{\Delta}_{0.06}$ & $\begin{array}{l}\text { コーヒー・茶系飲料 } \\
\text { 冷凍誠理食品 } \\
\text { リキュュール }\end{array}$ & $\begin{array}{l}\text { ビール } \\
\text { 野菜漬物 } \\
\text { 果先飲料 }\end{array}$ \\
\hline & プラスチック製品T業 & $\mathbf{\Delta} 1.2$ & 0.05 & $\begin{array}{l}\text { プラスチック製機械器其部品 } \\
\text { プラスチック製フィルムシート } \\
\text { プラスチック製板 }\end{array}$ & $\begin{array}{l}\text { プラスチック製パイプ } \\
\text { H用品・雑貨プラスチック製品 } \\
\text { 発泡プラスック製品 } \\
\end{array}$ \\
\hline & 石油·石炭製品工業 & $\mathbf{\Delta} 2.0$ & $\mathbf{\Delta}_{0.07}$ & $\begin{array}{l}\mathrm{B} \cdot \mathrm{C} \text { 重油 } \\
\text { ガソリン } \\
\text { ナフサ }\end{array}$ & $\begin{array}{l}\text { 軽油 } \\
\text { ジェッ燃料油 } \\
\text { アスファルト }\end{array}$ \\
\hline
\end{tabular}

（注）加工型業種，素形材業種，その他の業種の下に記してある数值は，上段：前年比（\%)， 卜段：寄与度（\%ポイント）である。

肥料, 化粧品が減少したものの，有機薬品，合成ゴム，石油系 芳香族などが増加したことにより前年比 $1.1 \%$ と 14 年の横ばいを 挟んで3年ぶりの上昇, 出荷は, 写真感光材料, 化学肥料, 石

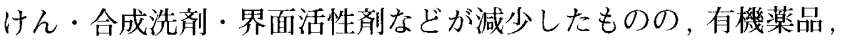
高圧ガス，石油系芳香族などが増加したことにより同 $1.3 \%$ と 2 年連続の上昇，在庫は，プラスチック，無機薬品・顔料・触媒， 化学肥料などが減少したものの，化粧品，環式中間物・合成染 料，有機薬品などが増加したことにより前年末比横ばいとなっ た。

1. 石油・石炭製品工業生産は, B-C重油, ガソリン, 灯油などの増加により前年比 $1.8 \%$ と 2 年ぶりの上昇となった。 出荷は同 $2.0 \%$ と年ぶりの上昇, 在庫も同 $9.4 \%$ と年ぶりの上 昇となった。 m. プラスチック製品工業生産は, 生産資材関連, 消費 資材関連が増加したことから前年比 $0.8 \%$ と 3 年ぶりの上昇, 出 荷は，生産資材関連，消費資材関連，土木建築用資材関連とす べて増加したことから同1.2\%と6年ぶりの上昇, 在庫は, 生産 資材関連, 消費資材関連, 土木建築用資材関連とすべて減少し たことから前年末比 $\mathbf{\Delta} 2.2 \%$ と 2 年連続の低下となった。

n. パルプ・紙・紙加工品工業 生産は, 紙加工品が増加 したものの，紙，板紙，パルプが減少したことから前年比 $0.5 \% の$ 低下, 出荷は, 紙加工品が増加したものの, 紙, 板紙, パルプが減少したことから前年比 $\mathbf{\Delta} 0.5 \%$ の低下, 在庫は, 板紙, 紙加工品が減少したものの, 紙, パルプが増加したことから前 年末比 $3.1 \%$ と年ぶりの上昇となった。

o. 繊維工業生産は, 国内需要の低迷に加え, 製品輸入 
增加の影響を受け，川上から川下段階までの減産継続により， 衣類，織物，化学繊維などすべての業種が減少し前年比 $\mathbf{A} 7.9 \%$ と1989年以降15年連続の低下，出荷も，衣類，織物，化学㵶維 などすべての業種が減少し前年比 $\mathbf{A} 8.7 \%$ と生産同様 15 年連続の 低下, 在庫は, 織物, 衣類, 化学繊維などすべての業種が減少 したことから前年末比・6.5\%の低下となった。

〔永壽 伴章 (独) 産業技術総合研究所〕

\section{$1=2$ \\ 工業研究}

\subsection{1 研究費, 研究者数の動き}

2002年度の我が国の自然科学の研究費は, 図 1 に示すように, 15.4 兆円（前年度比 $1 \%$ 増加）, 人文・社会科学を加えた研究費 総額は 16.7 兆円（前年度比 $0.9 \%$ 増加）である。

自然科学の研究費のうち，産業界が負担する割合は $79.9 \%$, 使用する割合は77.2\%である。

研究者数は, 図 2 に示すように, 自然科学のみで 63.7 万人 (大学の研究兼務者を除く，産業界は 44.0 万人), 人文・社会科
学を含めると75.7万人であり, 前年度と比べてほぼ横ばいであ る(表 3 ).

\section{$1 \cdot 2 \cdot 2$ 機械工業の研究開発の 現状について}

業種別に研究費を見ると，図 3 に示すように，電気機械が 3.8 兆円と多く，製造業全体の $37.8 \%$ を占めている，さらに，付加 価值に占める研究費の比率を見ても，電気機械が $29.8 \%$ と高く なっている.

1980年代から1990年代への変化を見ると，図 4 に示すように， 付加価値に対する研究費は増加しているものの, 付加価値の年 平均伸び率は減少している。

\section{1・2*3. 機械工業の技術貿易について}

2002年度の技術輸出は, 図 5 に示すように，1兆3 868億円で 前年度より $11 \%$ 増加して過去最高となり, 技術輸入は5 417億円 で前年度より $1 \%$ 減少した。

技術輸出のうち海外の親子会社からの受取額は9 657億円（受 取額全体の $70 \%$ ），技術輸入のうち海外の親子会社への支払額

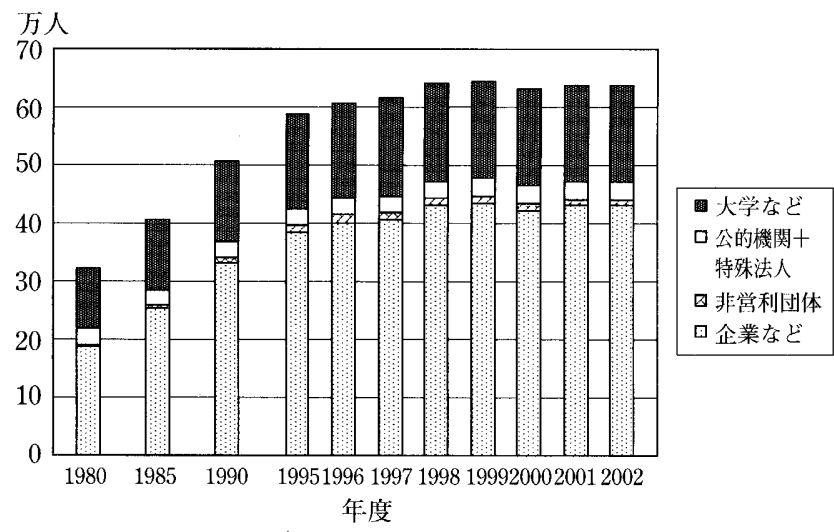

図 2 我が国の研究者数の推移 (自然科学のみ) ${ }^{(4)}$ （注） 2000 年度以前の非営利団体は民営研究機関の值を使用 (注) 大学などの研究者は, 研究本務者のみの值
（注）組織別使用研究費については，「産」=企業など十非営利団体， 「官」=公的機関十特殊法人,「学」=大学など

（注）2000年度以前の非営利団体は民営研究機関の值を使用

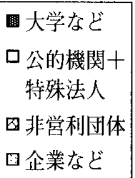

表 3 我が国の研究費および研究数の推移（自然科学のみ） ${ }^{(4)}$

\begin{tabular}{|c|c|c|c|c|c|c|c|c|c|}
\hline 年 度 & & 1995 & 1996 & 1997 & 1998 & 1999 & 2000 & 2001 & 2002 \\
\hline $\begin{array}{l}\text { 支出源別負担研究費 } \\
\text { 官 } \\
\text { 艮 } \\
\text { 外国 } \\
\end{array}$ & $\begin{array}{l}\text { 研究費 } \\
\text { 研究費 } \\
\text { 研究費 }\end{array}$ & $\begin{array}{r}2866 \\
10310 \\
15 \\
\end{array}$ & $\begin{array}{r}2725 \\
11102 \\
14 \\
\end{array}$ & $\begin{array}{r}2776 \\
11673 \\
43 \\
\end{array}$ & $\begin{array}{r}3031 \\
11746 \\
48 \\
\end{array}$ & $\begin{array}{r}3060 \\
11593 \\
58 \\
\end{array}$ & $\begin{array}{r}3096 \\
11828 \\
64 \\
\end{array}$ & $\begin{array}{r}3044 \\
12138 \\
65 \\
\end{array}$ & $\begin{array}{r}3029 \\
12310 \\
59 \\
\end{array}$ \\
\hline $\begin{array}{c}\text { 組織別使用研究費および研究 } \\
\text { 産 企業など } \\
\text { 非営利団体 } \\
\text { 宫 公的研究機関 } \\
\text { 特殊法人 } \\
\text { 大学 }\end{array}$ & $\begin{array}{l}\text { 研究費 } \\
\text { 研究者数 } \\
\text { 研究費 } \\
\text { 研究者数 } \\
\text { 研究費 } \\
\text { 研究者数 } \\
\text { 研究費 } \\
\text { 研究者数 } \\
\text { 研究費 } \\
\text { 研究者数 }\end{array}$ & $\begin{array}{r}9396 \\
384100 \\
571 \\
13387 \\
744 \\
24230 \\
605 \\
3915 \\
1875 \\
161304\end{array}$ & $\begin{array}{r}10058 \\
400361 \\
610 \\
14014 \\
704 \\
24076 \\
585 \\
3914 \\
1883 \\
164419\end{array}$ & $\begin{array}{r}10658 \\
404232 \\
653 \\
14128 \\
728 \\
24228 \\
546 \\
4201 \\
1906 \\
167493\end{array}$ & $\begin{array}{r}10800 \\
429195 \\
650 \\
13566 \\
737 \\
24441 \\
625 \\
4613 \\
2012 \\
166858\end{array}$ & $\begin{array}{r}10630 \\
433758 \\
645 \\
13826 \\
750 \\
24513 \\
695 \\
4686 \\
1990 \\
167209\end{array}$ & $\begin{array}{r}10860 \\
421363 \\
661 \\
13943 \\
745 \\
24420 \\
733 \\
4859 \\
1989 \\
166731\end{array}$ & $\begin{array}{r}11451 \\
430688 \\
336 \\
9829 \\
454 \\
17042 \\
990 \\
14770 \\
2015 \\
165512\end{array}$ & $\begin{array}{r}11577 \\
431190 \\
309 \\
9592 \\
431 \\
16546 \\
1012 \\
15487 \\
2068 \\
164381\end{array}$ \\
\hline 自然科学 & $\begin{array}{l}\text { 研究費 } \\
\text { 研究者数 }\end{array}$ & $\begin{array}{r}13191 \\
586936 \\
\end{array}$ & $\begin{array}{r}13841 \\
606784 \\
\end{array}$ & $\begin{array}{r}14492 \\
614282 \\
\end{array}$ & $\begin{array}{r}14824 \\
638673 \\
\end{array}$ & $\begin{array}{r}14710 \\
643992 \\
\end{array}$ & $\begin{array}{r}14988 \\
631316 \\
\end{array}$ & $\begin{array}{r}15246 \\
637841 \\
\end{array}$ & $\begin{array}{r}15398 \\
637196 \\
\end{array}$ \\
\hline 統計（自然科学十人文科学） & $\begin{array}{l}\text { 研究費 } \\
\text { 研究者数 }\end{array}$ & $\begin{array}{r}14408 \\
673421 \\
\end{array}$ & $\begin{array}{r}15079 \\
695623 \\
\end{array}$ & $\begin{array}{r}15742 \\
704514\end{array}$ & $\begin{array}{r}16140 \\
732658\end{array}$ & $\begin{array}{r}16011 \\
739504\end{array}$ & $\begin{array}{r}16289 \\
728215\end{array}$ & $\begin{array}{r}16528 \\
756336\end{array}$ & $\begin{array}{r}16675 \\
757339\end{array}$ \\
\hline
\end{tabular}

（注1）2000年度以前の総計の研究者数は，研究本務者のみの数値

(注2) 2001 年度打よび2002年度の組織別研究者数の大学研究者には研究兼務者を含まない.人文・社会科学を含めた総計の大学研究者数に は研究兼務者の垁数を含む 